\title{
Seiches stimulate transient biogeochemical changes in a microtidal coastal ecosystem
}

\author{
Gotzon Basterretxea ${ }^{1, *}$, Antoni Jordi ${ }^{1}$, Esther Garcés ${ }^{2}$, Silvia Anglès ${ }^{2}$, Albert Reñé ${ }^{2}$ \\ ${ }^{1}$ Instituto Mediterráneo de Estudios Avanzados, Universidad de las Islas Baleares y el Consejo Superior de Investigaciones \\ Científicas (UIB-CSIC), Miquel Marqués 21, 07190 Esporles, Mallorca, Spain \\ ${ }^{2}$ Institut de Ciències del Mar, Consejo Superior de Investigaciones Científicas (CSIC), Pg. Marítim de la Barceloneta, 37-49, \\ 08003 Barcelona, Spain
}

\begin{abstract}
We examined the short-term hydrodynamic variability associated with atmospherically forced seiches at a microtidal Mediterranean embayment, its influence in nutrient pumping from the sediment, and the response of phytoplankton. During June 2007, 2 episodes of high-frequency atmospheric pressure fluctuations generated resonant sea-level oscillations. The observed sea-level oscillations varied slightly in both spectral composition and energy, exhibiting 3 predominant oscillation periods: 8.1, 15.2, and 32.9 min. Unusual pulsed increases in dissolved inorganic nitrogen (DIN) and dissolved inorganic phosphate $\left(\mathrm{PO}_{4}\right)$ concentrations in nearshore seawater were observed a few hours after the commencement of the first seiche. Peak nutrient concentrations in DIN $\left(26 \mu \mathrm{mol} \mathrm{l^{-1 }}\right)$ and $\mathrm{PO}_{4}\left(0.35 \mu \mathrm{mol} \mathrm{l}^{-1}\right)$ were comparable to sediment porewater values, suggesting that the source of enrichment was the hydraulically driven flux through the permeable sediment. Rapid responses in the size spectra of the phytoplankton community, mainly composed of flagellates, were observed in response to perturbations induced by the seiches. Numerical analysis of the submarine porewater exchange revealed that the $8.1 \mathrm{~min}$ sea-level oscillations efficiently forced benthic fluxes. This seiche period particularly affected the surveyed area. Our results show a mechanism by which large-scale forcing drives the local ecosystem dynamics, and emphasizes the importance of episodic events in the bottom-up control of microalgal communities in shallow coastal areas.
\end{abstract}

KEY WORDS: Seiches $\cdot$ Coast $\cdot$ Nutrients $\cdot$ Phytoplankton $\cdot$ Mediterranean Sea

\section{INTRODUCTION}

Shallow coastal waters are deeply dynamic ecosystems that respond promptly to changes that occur within them. This variability is attributed to the complex interaction of processes acting at various temporal and spatial scales, such as physical forcings or geochemical reactions of either natural or anthropogenic origin and their effects on community structure and food-web interactions (e.g. Cloern 1999, Lucas et al. 1999). An example is the large difference in the magnitude and type of responses that coastal ecosystems exhibit in response to nutrient enrichments (Cloern 2001). While mid-term relationships (i.e. from fortnightly to seasonal) between physicochemical and biological processes are generally well founded, much less is known about shorter-term and episodically operating processes. However, these short-term processes explain, to a large extent, the variable nature of coastal ecosystems, representing an essential part of our understanding of the biogeochemistry of coastal areas and their future response to climate variability. Comprehension of the interplay among meteorological forcings, hydrological variability, and ecosystem responses on this timescale is central to the understanding of processes such as transient proliferations of phytoplankton and, more specifically, harmful algal bloom events.

In contrast to pelagic regions and coastal upwelling areas, where plankton dynamics are primarily regulated by vertical stability and cross-pycnocline transport, land and benthic fluxes have a greater signifi- 
cance in the shallow coastal domain. Both rivers and groundwaters entrain large pools of nutrients, and processes enhancing their exchange with coastal waters have significant implications for the chemistry of littoral areas and, consequently, for the food-web dynamics. Allochthonous inputs regulate the dynamics of coastal areas receiving rainfall or freshwater inputs throughout the year; but in regions lacking important riverine sources, local processes, many of which occur in sediments, may be more consistent contributors to nearshore nutrient budgets, thus dominating plankton variability most of the time. Indeed, in regions such as the Mediterranean Sea, phytoplankton distributions display shoreward biomass gradients with strong inflections in the proximity of the coastline and differentiated communities (e.g. Kress et al. 2005), suggesting the relevance of groundwater-borne nutrients in the biogeochemistry of these nearshore waters.

In shallow sandy sediments, water motion keeps the surface layers unconsolidated and highly permeable to water flow. In these permeable beds interfacial porewater fluxes are driven by forcings, altering diffusion, advection, or resuspension rates (Oldham \& Lavery 1999, Burnett et al. 2003, Kirillin et al. 2009). These transport processes link mineralization in the sediments to production in the overlying water column (Huettel et al. 1998). Even though most of the factors affecting these exchanges at periodical rates are acknowledged (e.g. tidal, seasonal), there is a high degree of uncertainty in the biochemical role of transient events. For example, evidence shows that intense forcing episodes, such as hurricanes and tropical cyclones, may vary coastal productivity rates by altering, flushing, mixing, and discharging of submarine groundwater (Hu et al. 2006, Miller et al. 2006). Less information is available on other enrichment processes such as long period waves, which are less intensive but generally more frequent in some coastal regions and can thus be more relevant in sustaining coastal phytoplankton communities.

Long-period waves in the range of 10 to $100 \mathrm{~min}$ (seiches) typically occur in bays, harbors, and other semi-enclosed environments, in response to external forcings. These barotropic standing waves are commonly observed in the form of small amplitude sealevel oscillations along exposed coasts, and occasionally at sites of elongated morphology, where they can reach destructive proportions (Gomis et al. 1993). More frequently, seiche-induced movements produce barely perceivable sea-level variations that affect the hydraulic pressure gradients and current intensifications that resuspend sediments and other particulate material from the seafloor (Jordi et al. 2008, Anglès et al. 2010). Alteration of bottom pressure gradients may also force groundwater flow through the pore spaces ('ventilation'), transporting solutes, small particles, biota, and even altering benthic metabolism (Rusch \& Huettel 2000, Falter et al. 2005, 2007). In the case of seiches, these effects are most noticeable at the edges of the oscillating system, thus being most significant for nearshore environments. In particular, they are known to be relevant for the biogeochemistry of lakes and freshwater reservoirs (e.g. Gloor et al. 2000), but information on their importance in coastal environments is limited. This lack of scientific evidence could be related to the fact that the effect of seiches in coastal biogeochemistry is hardly distinguishable from other short-term processes co-acting in the nearshore, such as tides.

Despite the occurrence of seiches in most of the world's oceans, they are particularly relevant in the Mediterranean because of their relative significance in total sea level oscillations and complex coastal morphology. There are evidences of seiche occurrence in the Balearic Islands, the Adriatic, and other regions, (Monserrat et al. 1991, 2006, Vilibiç \& Šepić 2009). In the Mediterranean, seiches present notable seasonality associated with synoptic atmospheric scenarios. Summertime conditions in the upper atmosphere appear to be favorable for these events, when seiching is notably active (Šepić et al. 2009).

In the present study, we focus on the biogeochemical consequences of seiches in a shallow embayment. We propose that the sea-level oscillations generated by seiches increase fluxes of inorganic nutrients from the sediment at the nearshore, producing significant shortterm changes in the phytoplankton community of the overlying waters. Although numerous studies have addressed groundwater and solute inputs to surface water bodies, few studies to date have documented the biochemical effects of seiches in coastal waters.

\section{MATERIALS AND METHODS}

Field site. The study area was a small embayment, Peguera, located in the northwestern coast of Santa Ponça Bay, Mallorca, Balearic Islands (Fig. 1). The embayment is relatively shallow $(\sim 2$ to $3 \mathrm{~m})$ and is protected from the sea in most directions. There are no permanent freshwater discharges into the embayment or nearby areas. Sediments are dominated by bioclastic sand with a median grain diameter of $0.29 \pm 0.08$ $\mathrm{mm}$, extending to a depth of some $6 \mathrm{~m}$. Below this level a seagrass meadow Posidonia oceanica extends to an approximate depth of $35 \mathrm{~m}$.

As with the rest of the Balearic Islands, this area experiences microtidal conditions, with a maximum spring range of $0.25 \mathrm{~m}$. Water level variations related to strong wind pulses and atmospheric pressure 


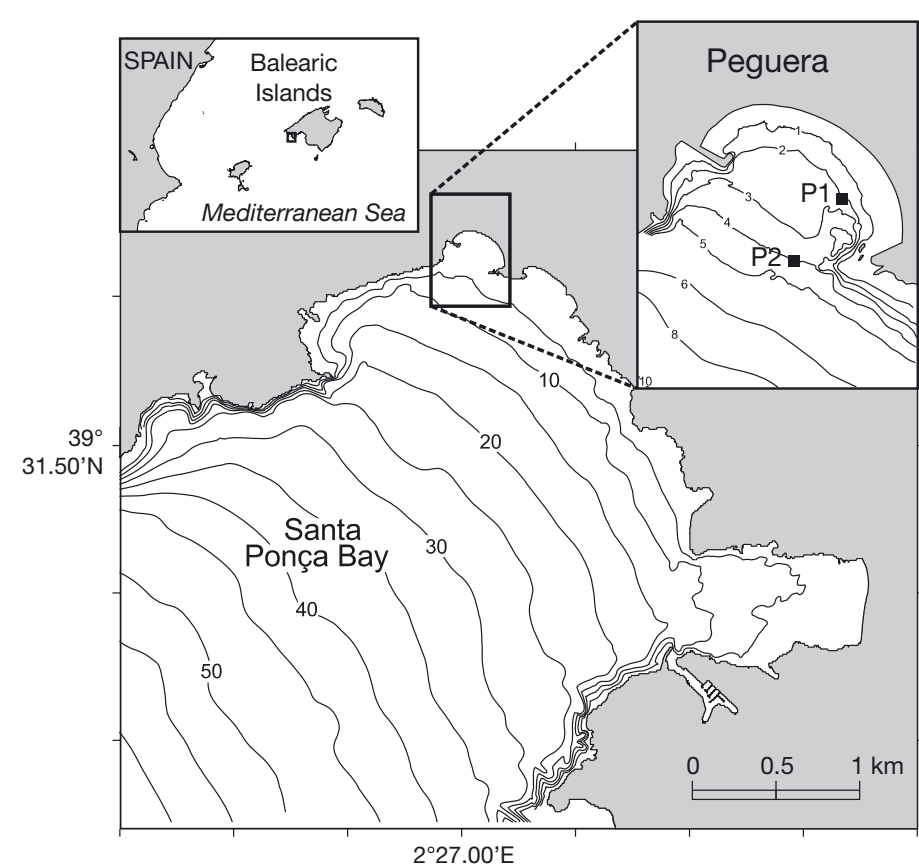

Fig. 1. Study site. The enlarged map shows the approximate bathymetry of the area surrounding the study site. P1 indicates the position of the Nortek Vector acoustic doppler velocity meter and the sampling site, and P2 marks the location of the sea-level sensor

changes often exceed the tidal range. Under persistent calm conditions of low water renewal, shorewards flow, high temperatures, and enhanced nutrient loads of a diffuse nature in the nearshore favor summer phytoplankton outbreaks of dinoflagellates of the genus Alexandrium and Gymnodinium at this beach (Basterretxea et al. 2005).

Sampling. Measurements were carried out between 20 and 25 June 2007, at a sampling point located some $100 \mathrm{~m}$ from the shoreline and at a depth of $2.4 \mathrm{~m}$ (P1, Fig. 1). Bi-hourly water samples were collected at an approximate depth of $0.30 \mathrm{~m}$ below the sea surface for dissolved inorganic nutrient analyses. Nutrient samples were frozen immediately after collection, and concentrations of nitrate, nitrite, ammonia, phosphate, and silicate were measured with a segmented-flow Alliance autoanalyzer. A total of 21 samples (150 ml each) were collected in order to calibrate a laser in situ scattering and transmissometry particle size analyzer (LISST-100X; Sequoia Scientific), with direct microscopy cell quantification measurements. The general procedure for identifying and quantifying phytoplankton involved sedimentation ( $24 \mathrm{~h}$ ) of a subsample fixed with Lugol's (1\% final concentration) in a $50 \mathrm{ml}$ settling chamber, and subsequent counting of cells within an appropriate area (depending on cell density) using a Nikon Diaphot 200 inverted microscope. At least half of the chamber was scanned at $200 \times$ magnification in each sample.

Interstitial waters were sampled near the shoreline ( $0.5 \mathrm{~m}$ depth) in the months preceding the survey (approximately every $2 \mathrm{wk}$ ) to measure porewater salinity and nutrient variations, as part of a groundwater survey program. A stainless steel shielded-screen drivepoint piezometer (Retract-a-Tip; AMS) was used in the 6 surveys carried out, to obtain water from 4 depths $(30,60,90$, and $120 \mathrm{~cm})$. The same nutrient analysis procedure as for seawater samples was used, except that porewater samples were filtered through glass fiber filters in order to remove sediment particles.

A free-falling self-contained autonomous microstructure profiler (SCAMP; PME) was used to obtain a time series over a period of $\sim 126 \mathrm{~h}$, consisting of 63 temperature profiles at P1 (Fig. 1). Salinity measurements were obtained only at the beginning of the sampling due to sensor failure. The instrument was set to obtain vertical microprofiles, acquiring samples in upward mode at a speed of $0.1 \mathrm{~m} \mathrm{~s}^{-1}$. Simultaneous particle size distribution profiles were obtained with a LISST-100X mounted on a slightly negatively buoyant profiling frame. Particle size distribution profiles obtained with the LISST-100X were used to determine the cell abundance of the nanoplankton (2 to $20 \mu \mathrm{m}$ ) and microplankton (20 to $200 \mu \mathrm{m}$ ) in the water column. The size factor distribution for each phytoplankton group was estimated from microscopy cell counts, using the size-fraction method to allow discrimination of particular species or groups from the LISST-100X measurements (Anglès et al. 2008). Good agreement was obtained between LISST-100X measurements and microscopy counts $(\mathrm{r}=0.93$ and 0.78 for nano- and microplankton, respectively; $\mathrm{n}=21$ ).

Flow velocity was measured at a distance of approx. $40 \mathrm{~cm}$ above the seafloor with a frequency of $8 \mathrm{~Hz}$ using a Nortek Vector acoustic doppler velocity meter (ADV). Sea-level variations were measured at $1 \mathrm{~min}$ intervals with a SBE-26 wave and tide recorder. Both devices were deployed close to each other at the study site: the ADV at P1 with water depths of some $1.5 \mathrm{~m}$ and the SBE-26 further offshore at P2 with a depth of $4 \mathrm{~m}$ (Fig. 1). Despite their shallowness, the sampling points were located in areas of unbroken waves. Meteorological conditions during the experiment were registered at Palma Airport, located some $20 \mathrm{~km}$ from the sampling site, at 10 min intervals.

Data analysis. Continuous wavelet transforms (CWTs) were used to determine the degree of nonstationary oscillations present in the sea-level time series. The application of the CWTs provides an effective method of analyzing and synthesizing the variable structure of a signal over time, and provides a means of localizing events of interest at their exact temporal 
location (Torrence \& Compo 1998). The advantages of utilizing wavelet analysis to study the dependence of sea-level variability on meteorological parameters have been demonstrated in previous studies (Drago $\&$ Boxall 2002). For the present study we choose a Morlet wavelet, commonly used in studies of geophysical processes.

Wave parameters, such as significant wave height, peak period, and direction, were derived at $10 \mathrm{~min}$ intervals from the wave directional spectrum, which was calculated from the ADV measurements using the DIWASP package (Johnson 2002). To elucidate the combined effect of waves and currents on sediment resuspension, bottom stress was estimated from the derived wave parameters, and the currents measured by the ADV according to the wave-current interaction model of Grant \& Madsen (1979).

Modeling. To reproduce and extend seiche motion on Peguera beach and Santa Ponça Bay a numerical circulation model (FUNDY) was used. FUNDY is a 3dimensional sigma-coordinate finite-element model based on linear shallow-water equations (Lynch et al. 1992). The algorithm uses conventional hydrostatic and Boussinesq approximations and Mellor-Yamada level 2.5 eddy viscosity closure. The computational domain extends along the southern shelf of Mallorca, as described in previous works (Basterretxea et al. 2005). The grid resolution was finer than $50 \mathrm{~m}$ in the Santa Ponça Bay. To evaluate the relative amplification of waves arriving from the shelf inside the bay, and the beach, the model was forced by barotropic waves of $1 \mathrm{~cm}$ amplitude and periods ranging from $1 \mathrm{~min}$ to $5 \mathrm{~h}$ at the model boundaries, which lie at the shelf break (200 m depth).

In addition, the effect of waves and seiche motion in the submarine porewater exchange was investigated with a 1-dimensional vertical advection-diffusion equation applied to the water column and the permeable sediment. Following Massel et al. (2005), vertical flow velocities were derived from gradients of seawater and porewater dynamic pressure under linear wave theory. Assuming a constant incident surface wave of height $H$ and angular frequency $\omega$, the dynamic pressure in the water column $\left(p_{\mathrm{w}}\right)$ is:

$$
p_{\mathrm{w}}(z, t)=\frac{\rho_{\mathrm{w}} g H}{2} \frac{\cosh \left[k\left(z+h_{\mathrm{w}}\right)\right]}{\cosh \left(k h_{\mathrm{w}}\right)} \exp (-i \omega t)
$$

where $z$ is the vertical co-ordinate, $t$ is time, $g$ is gravity $\left(9.81 \mathrm{~m} \mathrm{~s}^{-2}\right), \rho_{\mathrm{w}}$ is the water density $\left(1025 \mathrm{~kg} \mathrm{~m}^{-3}\right)$, $h_{\mathrm{w}}$ is the water depth $(2 \mathrm{~m})$ and $i=\sqrt{ }-1$. The incident wave number $(k)$ was estimated using the Airy linear wave theory for the wind waves, and using the FUNDY results for the seiche motion. The dynamic pressure in the permeable sediment $\left(p_{\mathrm{s}}\right)$, considering that the soil is completely saturated with water, is:

$$
p_{\mathrm{s}}(z, t)=p_{\mathrm{w}}\left(z=-h_{\mathrm{w}}, t\right) \frac{\cosh [k(z+h)]}{\cosh \left(k h_{\mathrm{s}}\right)}
$$

where $h$ is the depth of the non-permeable bottom ( $5 \mathrm{~m}$ ) and $h_{\mathrm{s}}$ is the thickness of the permeable sediment $(3 \mathrm{~m})$. The vertical flow velocities in the water $\left(w_{\mathrm{w}}\right)$ and in the permeable sediment $\left(w_{\mathrm{s}}\right)$ are:

$$
\begin{gathered}
w_{\mathrm{w}}(z, t)=\frac{1}{\rho_{\mathrm{w}}}\left|\frac{\partial p_{\mathrm{w}}}{\partial z}\right| \\
w_{\mathrm{s}}(z, t)=\frac{1}{n \rho_{\mathrm{w}} g}\left|\frac{\partial p_{\mathrm{s}}}{\partial z}\right| K_{\mathrm{f}}
\end{gathered}
$$

where $n$ is the sediment porosity $(0.26)$ and $K_{\mathrm{f}}$ is the filtration coefficient $\left(0.01 \mathrm{~cm} \mathrm{~s}^{-1}\right)$ derived from the Hazen formula (Massel 2001). Diffusivities were assumed to be constant in the water column $\left(5 \times 10^{-6} \mathrm{~m}^{2} \mathrm{~s}^{-1}\right)$ and negligible down into the sediment. The advectiondiffusion equation was integrated over $24 \mathrm{~h}$ forced by constant wind waves or seiche motions with periods coincident with the observations using a vertical grid of $0.1 \mathrm{~m}$ spacing. A conservative tracer was used to analyze the submarine porewater exchange. At initialization, porewater was assumed to be fully saturated with tracer $(100 \%)$, and undetectable concentrations $(0 \%)$ were considered to be present in the seawater. With the exception of the incident wave parameters (see 'Discussion'), results of the advection-diffusion equation are quite insensitive to the model parameters.

\section{RESULTS}

\section{Atmospheric conditions}

Fig. 2a displays the average synoptic surface pressure situation between 22 and 25 June. A depression situated over the Iberian Peninsula with a pronounced air-pressure gradient generated southerly to southwesterly winds in the western Mediterranean. These conditions have been reported to favor the formation of atmospheric pressure gravity waves with periodicities in the range of minutes (see Monserrat et al. 1991). Local atmospheric pressure data, recorded at Palma airport, showed an increasing trend until noon of 23 June, and then a progressive decrease until 26 June (Fig. 2b). Most interestingly, 2 high-frequency oscillation events (E1 and E2) were registered early on 22 June, under increasing pressure variation, and more vigorously in the night of 23-24 June, with descending atmospheric pressure. In these episodes, spanning periods of approximately 14 and $9 \mathrm{~h}$, respectively, the atmospheric pressure varied only a few dbars.

With the exception of 22 June, when a transient decrease in solar radiation was recorded for some hours 


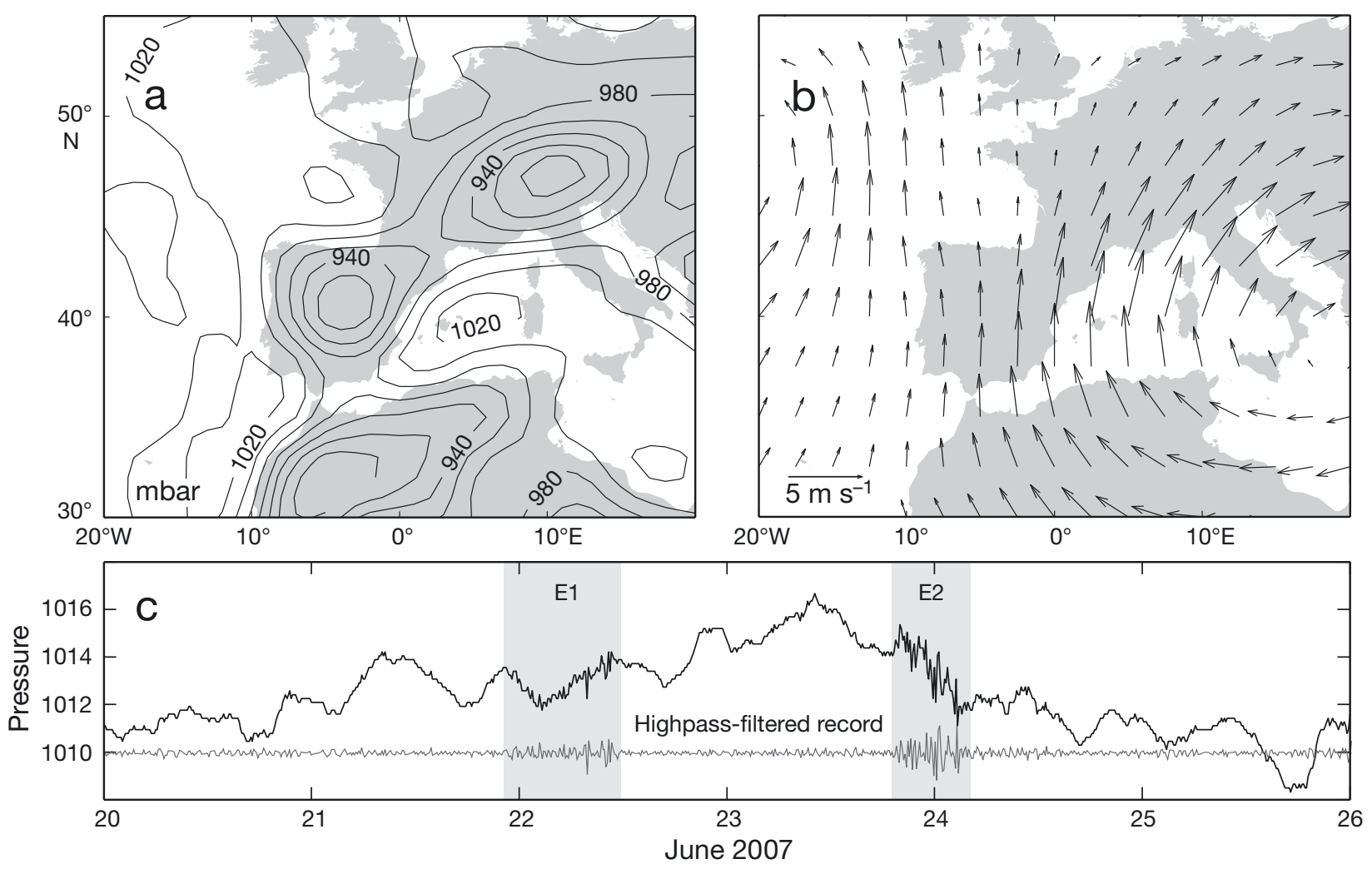

Fig. 2. (a) Surface atmospheric pressure and (b) wind charts (mean for 22 to 25 June) produced from National Center for Environmental Prediction reanalysis data provided by the NOAA Earth Systems Research Laboratory Physical Sciences Division, Boulder, CO, USA, from their web site at www.esrl.noaa.gov/psd/. (c) Temporal evolution of atmospheric pressure variation during the sampling period. The gray line shows the highpass-filtered pressure data (cutoff $=2 \mathrm{~h}$ ) revealing the 2 oscillation events (E1 and E2). An offset has been introduced for clarity

during the morning, clear skies predominated for most of the experiment. Wind records indicated that sea breeze conditions were experienced for the first days of the experiment. This local regime was disrupted on 23 June by winds blowing from the north, and then veering to the southwest at 12:00 h of 24 June. Nevertheless, winds were low $\left(<10 \mathrm{~m} \mathrm{~s}^{-1}\right)$ throughout the experiment.

\section{Oceanographic conditions}

Daily surface seawater temperature varied from $23^{\circ} \mathrm{C}$ at night to $27^{\circ} \mathrm{C}$ in the afternoon (Fig. 3). At this time, intense stratification developed in the surface layer (vertical gradient of $\sim 2.5^{\circ} \mathrm{C}$ ), particularly between 22 and 24 June. Calm seas were experienced for most of the study. The significant wave height and period decreased from a maximum of $0.4 \mathrm{~m}$ and $6 \mathrm{~s}$ during the first $2 \mathrm{~d}$ of the study to less than $0.2 \mathrm{~m}$ and $4 \mathrm{~s}$ in the last $3 \mathrm{~d}$. Currents were oscillatory and perpendicular to local bathymetry. Current speeds were low, being more intense $\left(\sim 5 \mathrm{~cm} \mathrm{~s}^{-1}\right)$ during the first days when the waves were larger. Current enhancements were also observed associated with the 2 highfrequency oscillation events of atmospheric pressure although significant changes in mean current vector direction were not detected in these episodes.

The bottom shear stress was also intensified during these periods, but always remained well below the theoretical limit $\left(0.35 \mathrm{~N} \mathrm{~m}^{-2}\right)$ for fine sediment resuspension. Presence of wind waves may also increase resuspension in the breaking zone. Indeed, as shown in Fig. 3d, the ADV signal strength, indicative of the concentration of sediment particles in the water $(\sim 100$ to $150 \mu \mathrm{m})$, showed higher counts in the days preceding to the seiche episodes, when wind waves were higher.

\section{Sea-level oscillations}

The sea-level records show a mixed tidal cycle and superimposed, higher-frequency oscillations with amplitudes exceeding the tidal range (Fig. 4). These intense seiche oscillations corresponded with the high frequency oscillation events of atmospheric pressure, 

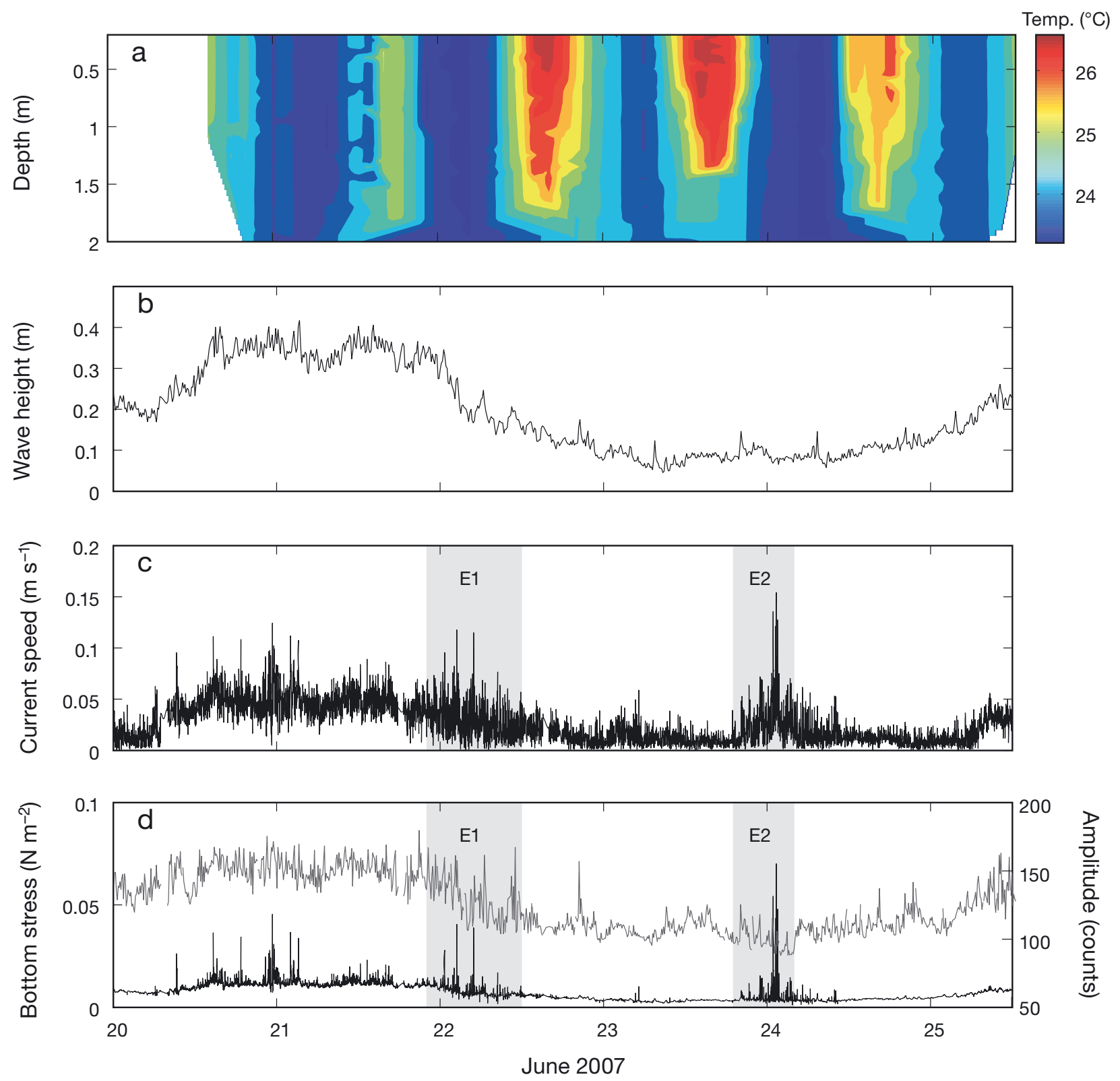

Fig. 3. Temporal evolution of (a) seawater temperature $\left({ }^{\circ} \mathrm{C}\right)$, (b) wave height, (c) near-bottom current speed, and (d) bottom stress. The gray line in (d) shows the amplitude of the ADV signal strength (right axis). E1, E2: oscillation events

but lasted for longer periods (about 2 d), decreasing progressively in intensity. Wavelet transformations of the sea-level record reveal energetic oscillations at periods in the range of 6 to 10 and 14 to $18 \mathrm{~min}$ and, more marginally, at 32 to $34 \mathrm{~min}$. The energy corresponding to these bands was computed by integrating sea-level spectra between the corresponding bands at $1 \mathrm{~h}$ intervals. Temporal evolution of the energy shows that each oscillation event is composed of pulses of 1 to $3 \mathrm{~h}$, which did not occur simultaneously. Moreover, the response of these bands varied between both events. In E1 the energy first increased in the 6 to 10 min band, and a delayed response took place in the other bands, while E2 exhibited a more homogeneous response in the more energetic bands (6 to 10 and 14 to $18 \mathrm{~min}$ ).

FUNDY model results for sea-level amplification in the area are shown in Fig. 5. Generally, the spectral composition at the measuring site matches well with the above mentioned wavelet analysis, indicating that the model is able to simulate the main patterns of seiche dynamics in the area. Peaks are observed at 8.1, 15.2, and $32.9 \mathrm{~min}$. The spatial distribution of the $8.1 \mathrm{~min}$ period corresponds to fundamental seiche mode of Peguera embayment. The 15.2 min mode shows the seiche response associated with the Santa 


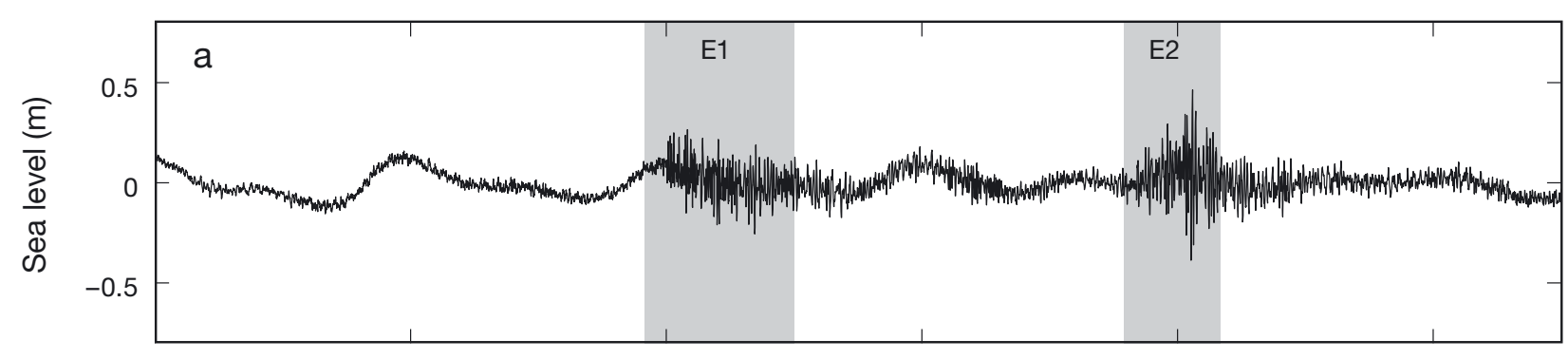

Wavelet
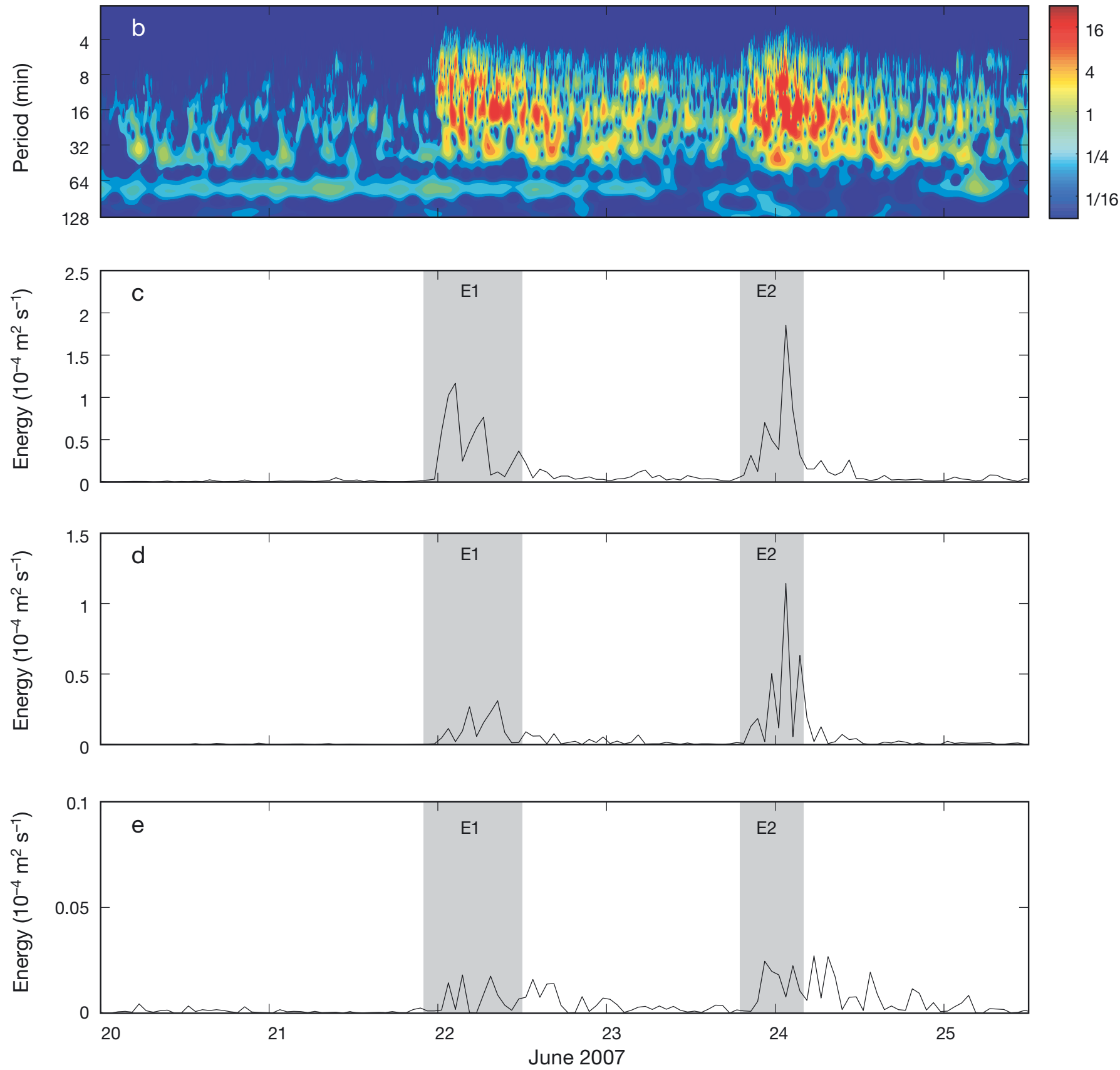

Fig. 4. Temporal evolution of (a) sea-level variation, (b) wavelet spectrum of sea-level oscillations, and sea-level energy at (c) the 6 to 10 min band, (d) the 14 to 18 min band and (e) the 32 to 34 min band. E1, E2: oscillation events 

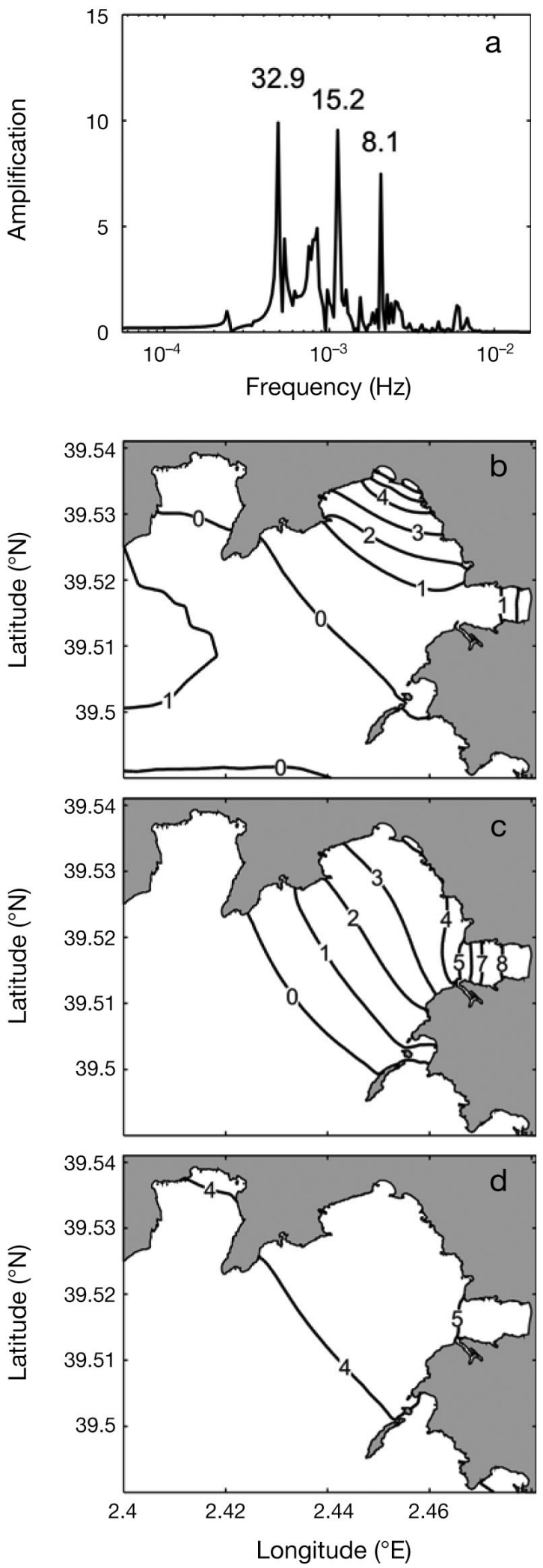

Fig. 5. (a) Amplification spectra, (b) spatial distribution of the 8.1 min amplification map, (c) 15.2 min amplification map, and (d) 32.9 min amplification based on FUNDY model results
Ponça Bay; the node is located at the outer boundary and presents a strong amplification in the eastern inlet. Finally, the 32.9 min period has a larger spatial scale because it is the dominant free wave mode of the Balearic shelf (Liu et al. 2002).

\section{Dissolved inorganic nutrient concentrations in porewater and seawater}

Fig. 6 shows the average vertical distribution of porewater salinity and macronutrients in the 6 piezometric profiles collected near the shoreline at different dates. In the upper layer $(0.3$ to $0.9 \mathrm{~m})$ porewater salinities remained relatively homogeneous, slightly decreasing with depth.

Porewater nutrient concentrations increased with depth, especially in the upper $\mathrm{cm}$ of the sediment. DIN concentrations averaged $15.0 \pm 4.6 \mu \mathrm{mol} \mathrm{l}^{-1}$, with concentrations generally exceeding $9 \mu \mathrm{mol} \mathrm{l}^{-1}$. The dominant nitrogen form in the sediment was ammonium $\left(90.8 \pm 4.8 \%\right.$ of DIN), whereas nitrate $\left(>1 \mu \mathrm{mol}{ }^{-1}\right)$ and nitrite represented only marginal fractions. $\mathrm{PO}_{4}$ concentrations showed mean concentrations of $0.33 \pm$ $0.19 \mu \mathrm{mol} \mathrm{l} \mathrm{l}^{-1}$ in the porewater. Higher variation was observed in the deeper sediment layer $(>1 \mathrm{~m})$ where salinity was notably lower $(30.7 \pm 4.9 \mathrm{psu})$ and $\mathrm{PO}_{4}$ concentrations higher.

As shown in Fig. 7 the seawater nutrients showed a wide range of variation: 1.5 to 26.0 and 0.04 to $0.35 \mu \mathrm{mol} \mathrm{l}^{-1}$ for DIN and $\mathrm{PO}_{4}$, respectively. The average seawater nutrient concentrations were significantly lower than those in sediment porewater. As in the case of porewater, ammonium was, on average, the most abundant nitrogen form, but nitrate reached $24 \pm$
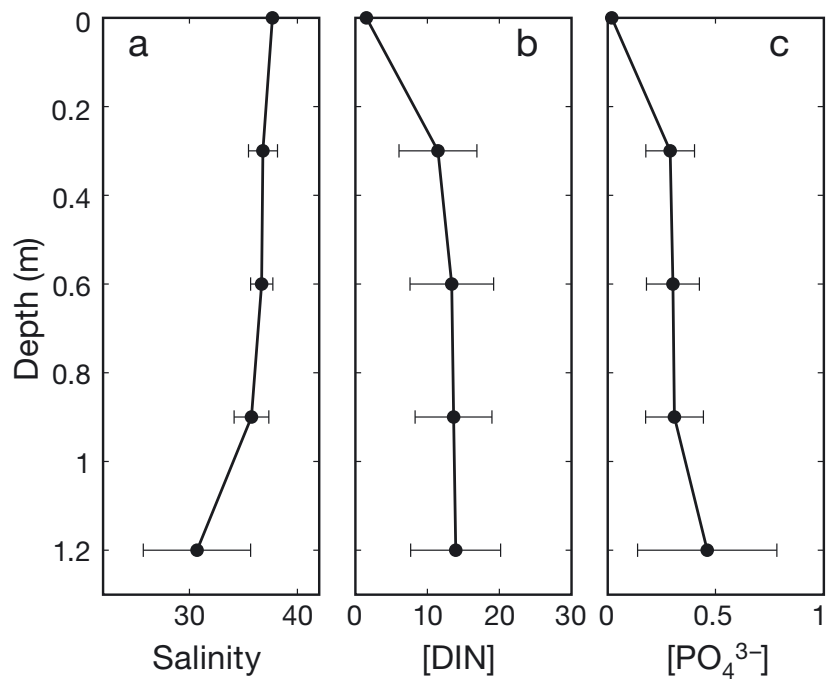

Fig. 6. Vertical distribution (average $\pm \mathrm{SD}$ ) of (a) salinity (psu), (b) dissolved inorganic nitrogen (DIN) and (c) $\mathrm{PO}_{4}$ concentrations $\left(\mu \mathrm{mol} \mathrm{l}^{-1}\right)$ in the sediment porewater 

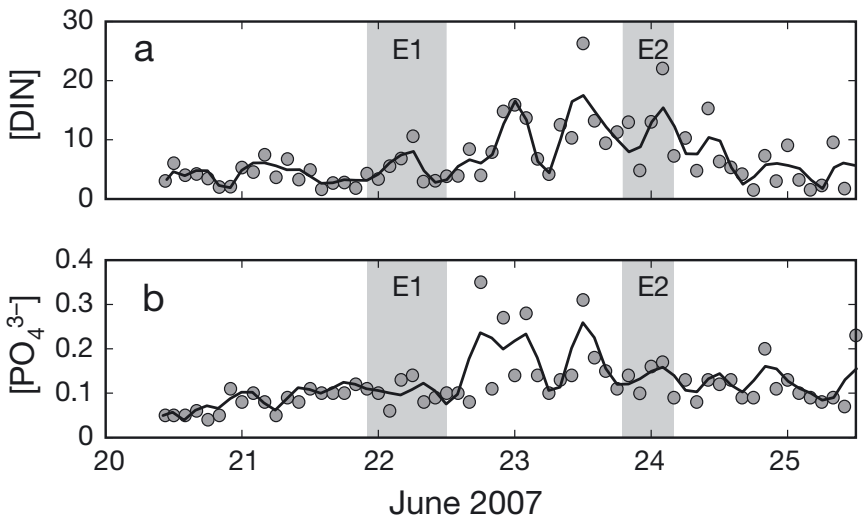

Fig. 7. Temporal evolution of (a) dissolved inorganic nitrogen (DIN) and (b) $\mathrm{PO}_{4}$ concentrations $\left(\mu \mathrm{mol} \mathrm{l}^{-1}\right)$ in seawater. The line indicates the lowpass-filtered series. E1, E2: oscillation events

$0.15 \%$ of DIN (data not shown). In the first days of the experiment, preceding the first seiche episode, the average dissolved inorganic nutrient concentrations were relatively high in comparison to offshore waters, but in agreement with previous studies in the area (e.g. Basterretxea et al. 2007).

A few hours after the first seiche episode began, a high dynamic range of concentrations in seawater was observed in DIN and $\mathrm{PO}_{4}$. Peak concentrations of DIN and $\mathrm{PO}_{4}$ were comparable, and occasionally exceeded mean porewater concentrations. This enhanced variability extended for some hours after the main seiche oscillations ceased. Yet, note in Fig. 4 that some oscillations persisted during this time. Since the effects of the first event overlap the second one (E2), it is difficult to resolve biochemical consequences of each of the episodes; nevertheless, effects of E2 appear to be weaker. Fig. 8 reveals the differences in seawater concentrations before and during the seiche episodes, and those in porewater. We consider pre-seiche period the hours preceding E1, and seiche period thereafter. In the case of both DIN and $\mathrm{PO}_{4}$ the seiche significantly increased the average seawater nutrient concentrations, but the increment for DIN ( 100\%) was relatively higher than that for $\mathrm{PO}_{4}(\sim 50 \%)$. Considering a Redfield N:P ratio of $16: 1$, most seawater samples showed an excess of DIN and a possible consequent $\mathrm{PO}_{4}$ limitation for algal growth. With some exceptions (i.e. $120 \mathrm{~cm}$ sample) the average porewater measurements show N:P ratios comparable to those of seawater (mean of $51 \pm 30$ and $60 \pm 30$, respectively).

\section{Phytoplankton community}

Nanoplankton and microplankton exhibited daily variations with maxima in the afternoons, and en-

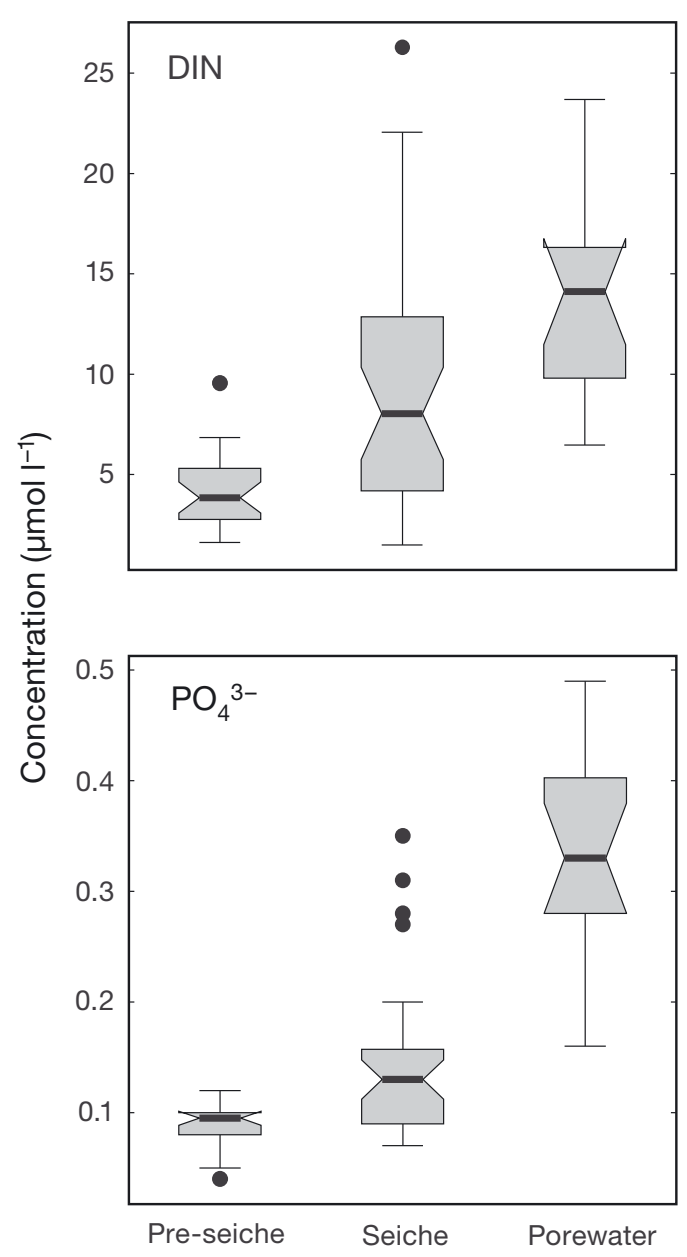

Fig. 8. Dissolved inorganic nitrogen (DIN) and $\mathrm{PO}_{4}$ concen-

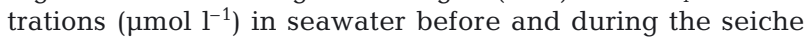
episodes, and in porewater $(0.25$ to $1 \mathrm{~m})$. The horizontal black line within each box is the median, and the boundaries of the boxes indicate the 25th and 75th percentiles. Error bars above and below the boxes indicate the 10th and 90th percentiles. Dots identify outlying points and notches are indicative of the confidence intervals

hanced abundances near the surface. There was a change in mean cell abundance observed beginning 22 June, when the seiche started (Fig. 9). Before the seiches, nanoplankton abundances remained below 1000 cells $\mathrm{l}^{-1}$ for most of the time, notably increasing

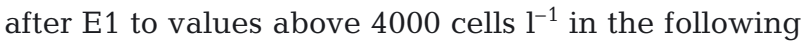
days (Fig. 9a). A 5-fold increase was registered for the microplankton, but with a lower degree of daily variation (Fig. 9b). The microplankton community consisted primarily of small dinoflagellates of the genera Alexandrium, Gymnodinium, Scrippsiella, and Heterocapsa ( $>60 \%$ of phytoplankton community). The latter was almost absent during the first $2 \mathrm{~d}$ of the survey, but increased to an abundance above 6000 cells $\mathrm{l}^{-1}$ after the first seiche episode E1 (data not shown). 


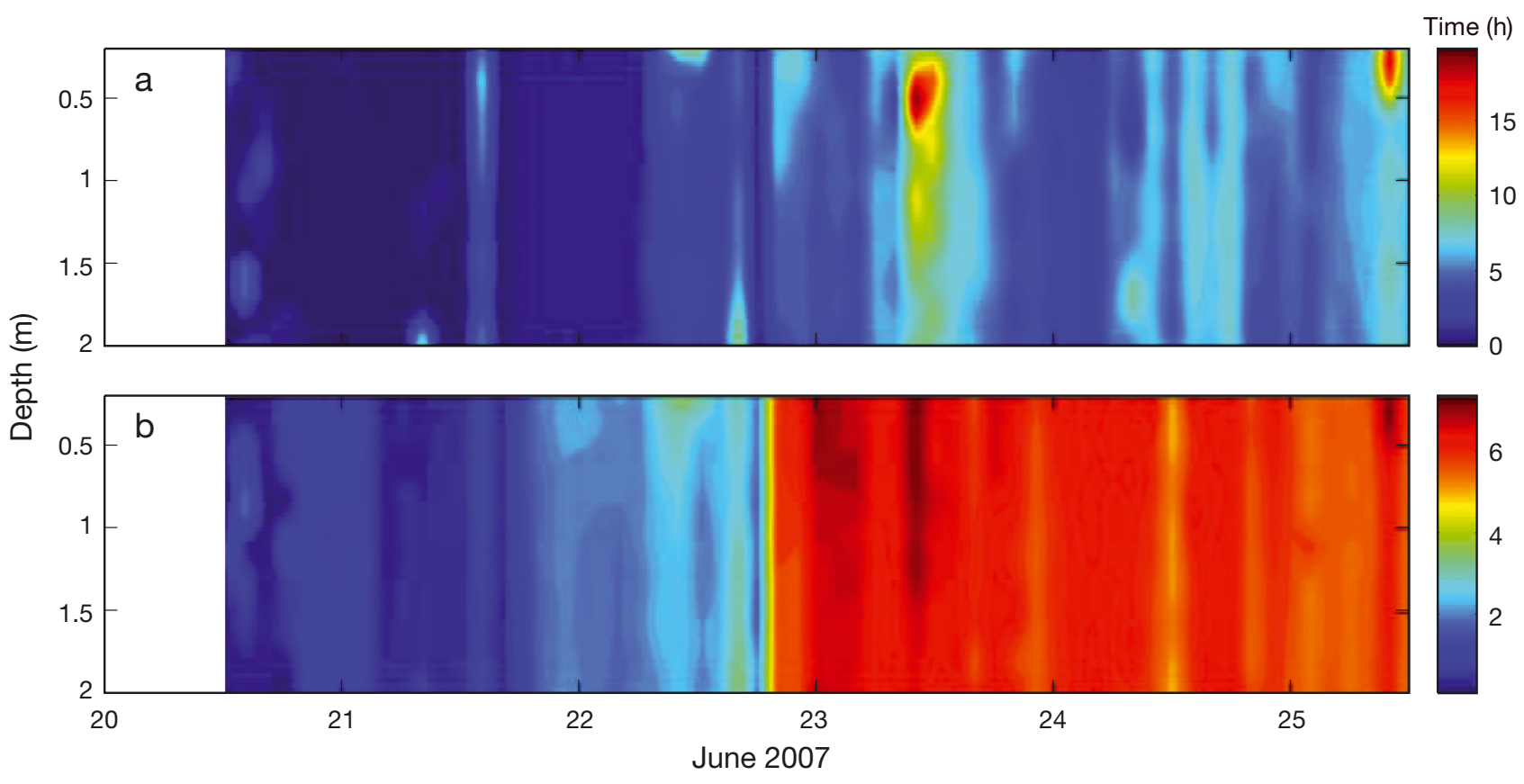

Fig. 9. Temporal evolution of (a) nanoplankton and (b) microplankton $\left(10^{3}\right.$ cells $\left.\mathrm{l}^{-1}\right)$

\section{Submarine porewater exchange}

Since peak seawater DIN and $\mathrm{PO}_{4}$ concentrations were comparable to porewater values, we hypothesize that the average seawater nutrient increments during seiches was caused by submarine porewater exchanges. The 1-dimensional vertical advectiondiffusion equation, described in 'Materials and methods: Modelling' section, was used to assess these porewater exchanges related to the observations of waves (height of $0.4 \mathrm{~m}$ and period of $6 \mathrm{~s}$ ) and seiches (amplitude of $0.2 \mathrm{~m}$ and periods of 8.1, 15.2, and $32.9 \mathrm{~min})$. Given the limitations of the vertical advection-diffusion equation (e.g. 1-dimensional, constant incident waves, parameter uncertainty), we should not expect to find high local (point-wise) correlations between the observed nutrient concentration and the modeled porewater exchange. Our intention is to quantify the magnitude of porewater exchange and to evaluate its influence on the observed nutrient increase.

Fig. 10a shows the averaged tracer concentration in the seawater column produced by porewater exchange during $24 \mathrm{~h}$ of constant wave and seiche forcing. Waves are more efficient in the porewater exchange in the short term $(<3 \mathrm{~h})$ because of the higher pressure gradients they produce. However, the exchange is restricted to the first $\mathrm{cm}$ of the sediment due to the short period ( $6 \mathrm{~s})$; thus, the effective exchange is low, and is even reduced at longer times. For the seiche, the $8.1 \mathrm{~min}$ oscillations induce a larger

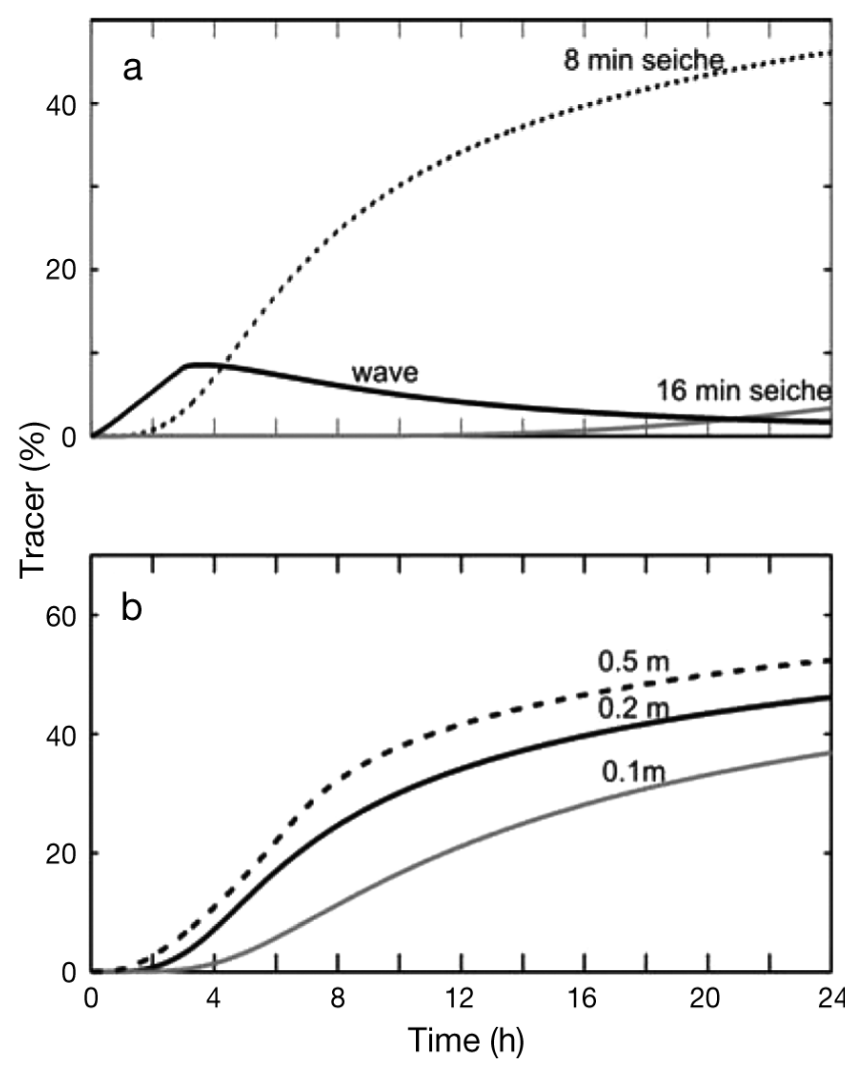

Fig. 10. Temporal evolution of the conservative tracer as a consequence of submarine porewater exchange forced by (a) a wave of $0.4 \mathrm{~m}$ and $6 \mathrm{~s}$, a seiche of $0.2 \mathrm{~m}$ and $8.1 \mathrm{~min}$, and a seiche of $0.2 \mathrm{~m}$ and $15.9 \mathrm{~min}$, (b) the same for a $8.1 \mathrm{~min}$ seiche of $0.5,0.2$, and $0.1 \mathrm{~m}$ 
porewater exchange than waves for periods longer than $4 \mathrm{~h}$, because of the duration of the period. However, the exchanges are drastically reduced for longer seiches (15.2 and $32.9 \mathrm{~min}$ ) as a consequence of the weaker pressure gradients. This indicates that tides (with longer periods) are not effective in the porewater exchange in the area under study.

Among the main seiche periods observed, the 8.1 min oscillation is the most effective in enhancing porewater exchange and it increases the seawater tracer concentration by about $38 \%$ after $14 \mathrm{~h}$, the approximate duration of E1. To evaluate the effect of this porewater exchange on the observed averaged nutrient concentrations, we assume that variations were only caused by porewater exchanges. The averaged values of DIN concentration for the porewater and the seawater before the seiche events were 15.0 and $3.9 \mathrm{\mu mol} \mathrm{l}^{-1}$, respectively. Considering that the preseiche average DIN concentration was $3.9 \mu_{\mathrm{mol}} \mathrm{l}^{-1}$, the $38 \%$ caused by the seiche would correspond to an average increase of about $4.2 \mu \mathrm{mol} \mathrm{l}{ }^{-1}$, which is consistent with the observed averaged increase of $4.1 \mu \mathrm{mol}$ $\mathrm{l}^{-1}$. In the case of $\mathrm{PO}_{4}$, the concentration in porewater was $0.33 \mu \mathrm{mol} \mathrm{l}^{-1}$, and the pre-seiche average concentration was $0.09 \mu_{\mathrm{mol}} \mathrm{l}^{-1}$. Hence, the increase would be about $0.09 \mu \mathrm{mol} \mathrm{\textrm {l } ^ { - 1 }}$, somewhat higher than the observed value $\left(0.05 \mu \mathrm{mol} \mathrm{l^{-1 }}\right)$. This indicates that, although the calculated nutrient enhancements do not exactly coincide with the observed values, porewater exchanges induced by the seiche are responsible of the observed nutrient increases. Note that we consider a $8.1 \mathrm{~min}$ seiche of constant amplitude $(0.2 \mathrm{~m})$. The $8.1 \mathrm{~min}$ oscillation with amplitude of $0.5 \mathrm{~m}$ can exchange enough porewater and increase the seawater column tracer concentration by about $40 \%$ in $10 \mathrm{~h}$, but even lower amplitudes provoke a significant exchange at this period of oscillation (Fig. 10b).

\section{DISCUSSION}

Our results provide evidence of a regional-scale process and atmospheric pressure oscillations that, even at low intensity, can provoke considerable short-time biogeochemical changes in the nearshore waters of a microtidal area, with implications for food web dynamics. In particular, we found marked changes in dissolved inorganic nutrient concentrations and phytoplankton composition in response to seiche events. High-frequency atmospheric fluctuations are sufficiently common to be considered as a usual feature of the Mediterranean Sea. The different response of semi-confined sites to seiches, together with the local characteristics of the benthic system (sediment permeability, infaunal activity, and interstitial nutrient pools), could explain, in some cases at least, why certain local ecosystems are more likely to experience phytoplankton blooms than others.

The release of nutrients from permeable sediments, and the subsequent transport upward, can play a decisive role in the trophic status of lakes and coastal environments, although the mechanisms driving this exchange are diverse. For example, the diffusive flux from the sediment is a continuous enrichment source in most shallow waters. This exchange may be favored by bioturbation (Kristensen \& Blackburn 1987), but even so, molecular diffusion is a slow process that is only considered dominant in cohesive sediments (Berner 1980). More effectively, porewater convection can occur in response to temperature variations produced by deeper water upwelling. Kirillin et al. (2009) suggest that this mechanism, which occurs at the intersection of the thermocline with the bottom sediment, can intensify up to 1000 -fold the dissolved matter exchange between the sediment and the water column in stratified lakes experiencing intense seiches. Alternatively, waves can generate advective porewater circulation in sandy beds. Precht \& Huettel (2003) demonstrated that pressure gradients generated by shallow-water waves can increase fluid exchange between sandy sediment and overlying water, but even low currents can be effective, causing porewater flows when sediment permeability is high. However, under stable summer conditions such as the ones analyzed here, continuous processes acting at shorter temporal scales than sediment remineralization and recycling, such as wind waves, tend to lose effectiveness over time. Moreover, short-period waves can stir porewater without producing net flows (Harrison et al. 1983).

In the present study, hydraulic pumping of interstitial water driven by the seiche is postulated as the principal process for the observed nutrient concentrations in seawater during the seiche. Unlike continuous processes, such as wave action, episodic events are more closely coupled with interstitial turnover rates, and therefore pulsed enrichment is in principle more effective than continuous wind wave action in inducing short-term plankton variability. Although we were unable to achieve direct sediment flux measurements during the seiche, because of the episodic nature of this phenomenon, other mechanisms do not seem to be responsible for the enhanced concentrations. For example, Ostrovsky et al. (1996) showed that seicheinduced mixing of hypolimnetic water enhanced the productivity of Lake Kinneret, but this process is unlikely to prevail in our case since the observed DIN concentrations are well above those observed under the seasonal thermocline in Mediterranean waters ( 1 to $5 \mu \mathrm{mol} \mathrm{l}^{-1}$ ). Also, the relevance of sediment resuspension in the generation of intermittent peaks in nu- 
trient concentrations and associated transportation of phytoplankton cells from the sediment into the water column is well documented (Shaffer \& Sullivan 1988, Garstecki et al. 2002). However, our ADV measurements indicate an absence of important resuspension events during the sampling period. Indeed, as suggested by the ADV signal strength, wave action was more effective than seiches in producing resuspension, and thus nutrient enhancement would be associated with increased wave action, which is not the case. Nevertheless, we are studying a relatively wide bay. In narrower inlets seiche-induced currents are stronger and could certainly produce sediment resuspension.

While all types of oscillations, including wind-waves, favor a certain degree of porewater exchange, damping of the wind-wave signal in the sediment is much higher than that of the seiche, and hence wind-waves only affect the shallowest depths causing relatively low nutrient fluxes. Falter \& Sansone (2000) thoroughly analyzed the effect of waves in porewater geochemistry. They report that if the spatial distribution of dissolved porewater species is a function of both their net reaction and transport rates, then changes in the hydrodynamic forces driving porewater transport rates should influence porewater composition. We basically agree with their results, except that they only considered wave height as a factor explaining the hydraulic control of porewater geochemistry. This may be valid for the range of periods affecting their study areas, but wave periods become important, and even more significant, when a wider oscillation spectrum is considered. In our case the depth from which porewater is exchanged is greater for periods closer to the $8.1 \mathrm{~min}$ seiche, and decreases for shorter (i.e. wind waves) and longer periods (Fig. 11).

With some overestimation in the case of $\mathrm{PO}_{4}$, numerical calculations of tracer transport by the $8.1 \mathrm{~min}$ seiches are consistent with the observed nutrient enhancements. We use a simple and 1-dimensional approximation and the fact that the observed seiche is not constant in time may induce some bias. Further, the model does not consider horizontal advection, and wind stress significantly varied on 23 June when a northerly wind episode began (Fig. 2). Basterretxea et al. (2007) demonstrated that northerly winds significantly reduce the residence time in the area by favoring seawards advection. Also, discrepancies between the conservative tracer concentrations and the observed nutrient values can be explained both by the different lability of DIN and $\mathrm{PO}_{4}$ and by phytoplankton uptake. In our case, high DIN concentrations remain for longer in seawater than $\mathrm{PO}_{4}$. Assuming Redfield requirements for phytoplankton growth, DIN would be in excess in these waters, and, hence, phosphate would decrease more rapidly suggesting a fast $P$ recycling.

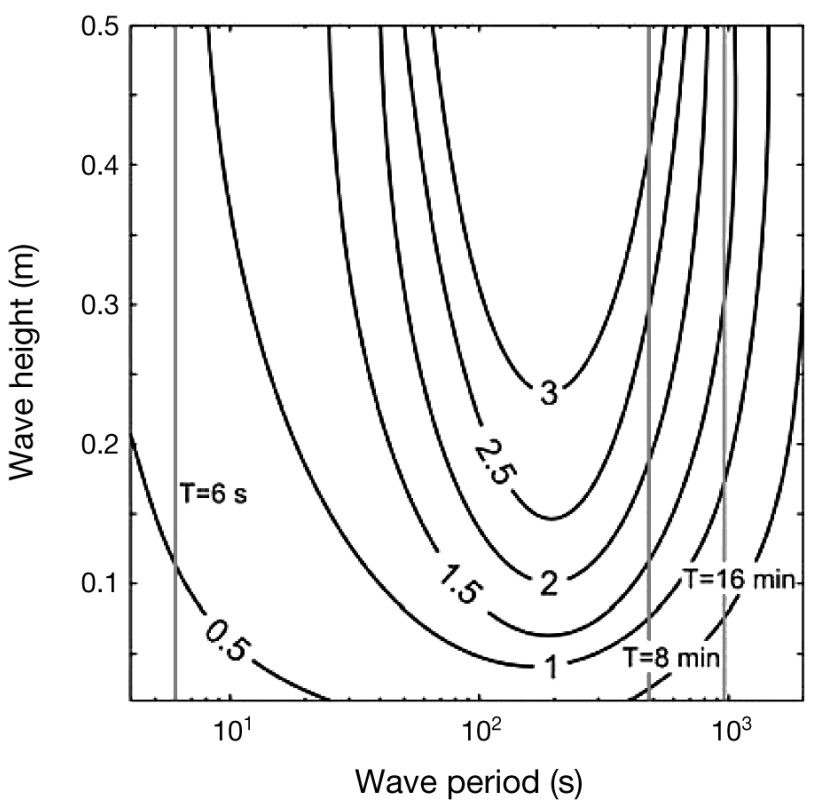

Fig. 11. Maximum depth $(\mathrm{m})$ of exchanged porewater as a function of wave period and amplitude after $24 \mathrm{~h}$ of simulation. The periods of $6 \mathrm{~s}, 8.1 \mathrm{~min}$, and $15.9 \mathrm{~min}$ are indicated by the gray lines

Our data suggest a reduced effect of E2 on nutrient release. Although, as mentioned before, we cannot resolve the effects of each episode, we can propose some mechanisms that explain this question. The duration of E2 was shorter than E1 (9 and $14 \mathrm{~h}$, respectively), and, as shown, nutrient release by hydraulic pumping is a function of time. Additionally, the distribution of energy in both events was different. E2 presented a more homogeneous response in the bands of 8.1 and $15.2 \mathrm{~min}$, but the latter did not significantly contribute to porewater exchange. Finally, the effect of seiches in the increase of seawater nutrients is limited by the depth from which porewater is exchanged and by the renewal time of the porous layer. Once this reservoir is exchanged, nutrient supply is limited by diffusion from deeper layers, which occurs over longer time scales.

Outflow from deeper layers not only results in enhanced advective nutrient exchange, but also has consequences in terms of sediment reoxygenation, and thus in the geochemistry of the sediment, as observed in other studies (Forster et al. 1996, Falter \& Sansone 2000). Eventual oxygen exposure of sediments increases the efficiency of benthic remineralization and alters the dissolution/precipitation equilibrium. In the carbonated sediments along the Mediterranean the dissolution/precipitation of carbonate plays an important role in the composition of the porewater, and this determines the nutrient ratios/concentrations in seawater with obvious consequences on algal growth. 
In our case, dissolved inorganic nutrient ratios in seawater suggest that phosphorous shortage might be the usual condition in Peguera Beach. This is also the case for other Mediterranean coastal locations (e.g. Tanaka et al. 2004). Phosphate loss from the water column, and from interstitial waters, results from adsorption or reaction with carbonate sediments and underlying limestone substrate, and iron hydroxides, as well as direct uptake by microorganisms. Dissolution of an ironphosphate complex is a key factor controlling the rate at which phosphorus is released. Measurements of sediment metabolism made by Sansone et al. (1990) indicate the importance of wave induced advective flows in setting the redox state of porous sediments. In our measurements, the prevalence of ammonium over other nitrogen forms indicates that reductive conditions prevail a few cm below the bottom boundary layer. In this context seiches act to produce an outflow of phosphorous-rich anoxic interstitial waters, and resetting the redox and absorption state of sediment particles reoxygenating the substrate. Thus the advective release of phosphorous is limited to the rate of change in the oxygen conditions in the sediment, suggesting that seiche action loses effectiveness over time.

In conclusion, our results show a mechanism by which large-scale atmospheric forcing may induce release of nutrients from the sediment and local ecosystem responses. We emphasize the importance of episodic events, such as seiches, in the bottom-up control of microalgal communities in shallow microtidal coastal areas. The overall influence of this mechanism in the occurrence of high density blooms of phytoplankton in the Mediterranean deserves further study.

Acknowledgements. This work was supported by the Consejo Superior de Investigaciones Científicas (CSIC) Intramurales project (Capas finas) and EHRE (CTM2009-08270). The work of A.J. and E.G. was supported by a JAE postdoctoral grant and a Ramón y Cajal award from the Ministerio de Ciencia e Innovación, respectively. The authors are most grateful to B. Casas, I. Álvarez, and L. Martinez-Ribes for their support in field work. We are also indebted to E. Cozar and the City Council of Calvià for facilitating the sampling. Meteorological data was provided by the Agencia Estatal de Meteorología.

\section{LITERATURE CITED}

> Anglès S, Jordi A, Garcés E, Masó M, Basterretxea G (2008) High-resolution spatio-temporal distribution of a coastal phytoplankton bloom using laser in situ scattering and transmissometry (LISST). Harmful Algae 7:808-816

Anglès S, Jordi A, Garcés E, Basterretxea G, Palanques A (2010) Alexandrium minutum resting cyst distribution dynamics in a confined site. Deep-Sea Res II 57:210-221

Basterretxea G, Garcés E, Jordi A, Masó M, Tintore J (2005) Breeze conditions as a favoring mechanism of Alexandrium taylori blooms at a Mediterranean beach. Estuar Coast Shelf Sci 62:1-12
Basterretxea G, Garcés E, Jordi A, Anglès S, Masó M (2007) Modulation of nearshore harmful algal blooms by in situ growth rate and water renewal. Mar Ecol Prog Ser 352: 53-65

Berner RA (1980) Early diagenesis: a theoretical approach. Princeton University Press, Princeton, NJ

> Burnett WC, Bokuniewicz H, Huettel M, Moore WS, Taniguchi M (2003) Groundwater and pore water inputs to the coastal zone. Biogeochemistry 66:3-33

Cloern JE (1999) The relative importance of light and nutrient limitation of phytoplankton growth: a simple index of coastal ecosystem sensitivity to nutrient enrichment. Aquat Ecol 33:3-15

> Cloern JE (2001) Our evolving conceptual model of the coastal eutrophication problem. Mar Ecol Prog Ser 210:223-253

Drago AF, Boxall SR (2002) Use of the wavelet transform of hydro-meteorological data. Phys Chem Earth 27:1387-1399

Falter JL, Sansone FJ (2000) Hydraulic control of porewater geochemistry within the oxic-suboxic zone of a permeable sediment. Limnol Oceanogr 45:550-557

Falter JL, Atkinson MJ, Coimbra CFM (2005) Effects of surface roughness and oscillatory flow on dissolution of plaster forms: evidence for nutrient mass transfer to coral reef communities. Limnol Oceanogr 50:246-254

> Falter JL, Atkinson MJ, Lowe RJ, Monismith SG, Koseff JR (2007) Effects of nonlocal turbulence on the mass transfer of dissolved species to reef corals. Limnol Oceanogr 52: $274-285$

> Forster S, Huettel M, Ziebis W (1996) Impact of boundary layer flow velocity on oxygen utilisation in coastal sediments. Mar Ecol Prog Ser 143:173-185

> Garstecki T, Wickham SA, Arndt H (2002) Effects of experimental sediment resuspension on a coastal planktonic microbial food web. Estuar Coast Shelf Sci 55:751-762

Gloor M, Wüest A, Imboden DM (2000) Dynamics of mixed bottom boundary layers and its implications for diapycnal transport in a stratified, natural water basin. J Geophys Res 105:8629-8646

> Gomis D, Monserrat S, Tintoré J (1993) Pressure-forced seiches of large amplitude in inlets of the Balearic Islands. J Geophys Res 98:14437-14445

Grant WD, Madsen OS (1979) Combined wave and current interaction with a rough bottom. J Geophys Res 84: 1797-1808

> Harrison WD, Musgrave D, Reeburgh WS (1983) A waveinduced transport process in marine sediments. J Geophys Res 88:7617-7622

> Hu CM, Muller-Karger FE, Swarzenski PW (2006) Hurricanes, submarine groundwater discharge, and Florida's red tides. Geophys Res Lett 33:L11601 doi:10.1029/2005 GL025449

> Huettel M, Ziebis W, Forster W, Luther GW (1998) Advective transport affecting metal and nutrient distributions and interfacial fluxes in permeable sediments. Geochim Cosmochim Acta 62:613-631

Johnson D (2002) DIWASP, a directional wave spectra toolbox for MATLAB: user manual. Centre for Water Research, University of Western Australia, Perth

Jordi A, Basterretxea G, Casas B, Anglès S, Garcés E (2008) Seiche-forced resuspension events in a Mediterranean harbour. Cont Shelf Res 28:505-515

Kirillin G, Engelhardt C, Golosov S (2009) Transient convection in upper lake sediments produced by internal seiching. Geophys Res Lett 36:L18601 doi:10.1029/2009GL040064

Kress N, Thingstad TF, Herut B, Zohary T and others (2005) Effect of $\mathrm{P}$ and $\mathrm{N}$ addition to oligotrophic eastern Mediterranean waters influenced by near-shore waters: a 
microcosm experiment. Deep-Sea Res II 52:3054-3073

Kristensen E, Blackburn T (1987) The fate of organic carbon and nitrogen in experimental marine sediment systems. Influence of bioturbation and anoxia. J Mar Res 45:231-237

Liu PFL, Monserrat S, Marcos M (2002) Analytical simulation of edge waves observed around the Balearic Islands. Geophys Res Lett 29:1847 doi:10.1029/2002GL015555

Lucas LV, Koseff JR, Monismith SG, Cloern JE, Thompson JK (1999) Processes governing phytoplankton blooms in estuaries. II: The role of horizontal transport. Mar Ecol Prog Ser 187:17-30

Lynch DR, Werner FE, Greenberg DA, Loder JW (1992) Diagnostic model for baroclinic, wind-driven and tidal circulation in shallow seas. Cont Shelf Res 12:37-64

Massel SR (2001) Circulation of groundwater due to wave setup on a permeable beach. Oceanologia 43:279-290

Massel SR, Przyborska A, Przyborski M (2005) Attenuation of wave-induced groundwater pressure in shallow water. II. Theory. Oceanologia 47:291-323

Miller WD, Harding LW, Adolf JE (2006) Hurricane Isabel generated an unusual fall bloom in Chesapeake Bay. Geophys Res Lett 33:L06612 doi:10.1029/2005GL025658

Monserrat S, Ramis C, Thorpe AJ (1991) Large-amplitude pressure oscillations in the western Mediterranean. Geophys Res Lett 18:183-186

Monserrat S, Vilibic I, Rabinovich AB (2006) Meteotsunamis: atmospherically induced destructive ocean waves in the tsunami frequency band. Nat Haz Earth Sys 6:1035-1051

Oldham CE, Lavery PS (1999) Porewater nutrient fluxes in a shallow fetch-limited estuary. Mar Ecol Prog Ser 183:39-47

Editorial responsibility: Alejandro Gallego, Aberdeen, UK
Ostrovsky I, Yacobi YZ, Walline P, Kalikhman I (1996) Seicheinduced mixing: its impact on lake productivity. Limnol Oceanogr 41:323-332

> Precht E, Huettel M (2003) Advective porewater exchange driven by surface gravity waves and its ecological implications. Limnol Oceanogr 48:1674-1684

> Rusch A, Huettel M (2000) Advective particle transport into permeable sediments - evidence from experiments in an intertidal sandflat. Limnol Oceanogr 45:525-533

Sansone FJ, Tribble GW, Andrews CC, Chanton JP (1990) Anaerobic diagenesis within recent, Pleistocene, and Eocene marine carbonate frameworks. Sedimentology 37: 997-1009

Šepić J, Vilibiç I, Monserrat S (2009) Teleconnections between the Adriatic and the Balearic meteotsunamis. Phys Chem Earth 34:928-937

Shaffer GP, Sullivan MJ (1988) Water column productivity attributable to displaced benthic diatoms in well-mixed shallow estuaries. J Phycol 24:132-140

Tanaka T, Rassoulzadegan F, Thingstad TF (2004) Orthophosphate uptake by heterotrophic bacteria, cyanobacteria, and autotrophic nanoflagellates in Villefranche Bay, northwestern Mediterranean: vertical, seasonal, and short-term variations of the competitive relationship for phosphorus. Limnol Oceanogr 49:1063-1072

Torrence C, Compo GP (1998) A practical guide to wavelet analysis. Bull Am Meteorol Soc 79:61-78

Vilibiç I, Šepić J (2009) Destructive meteotsunamis along the eastern Adriatic coast: overview. Phys Chem Earth 34: 904-917

Submitted: September 7, 2010; Accepted: November 23, 2010 Proofs received from author(s): January 26, 2011 